\title{
防風保温編地『ウィンドバリア ${ }_{\circledast}$ の開発
}

New Knitted Fabric $\left\ulcorner\right.$ WINDBARRIER $\left.{ }_{\circledast}\right\lrcorner$

尾 形 暢 亮·水木 光夫

\section{1.はじめに}

従来より、スポーツウェアは、ニット、織物共に弚れぞ れの生地特性を生かした用途で幅広く展開されてきた。消

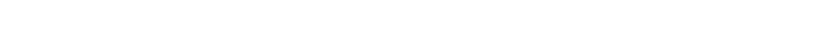
の特性を持ったウェアを選定し着替えや重ね着により衣服 内環境を快適に保ってきた。

最近、着替えや重ね着をしなくても、あらゆる着用環境 下で快適な衣服内環境を保つことが出来るオールラウンド ウェア開発のニーズが高くなってきている。

\section{2 . 開発の狙い}

ニット商品は、ルーズなループ構造の為、優れたストレッ チ性、ソフト風合い、嵩高性、ノイズレス性などの特長を 持っており、弚れを生かした用途て幅広く展開されている。

一方で、繊維間密度が低いため、防風性、撥水性、防水 性に乏しく、低温時や降雨時の着用には適さないという欠 点があり、光れらの用途では主に高密度織物が使用されて いる。

今回は、ニットの特長を保持したまま優れた防風性、撥 水性を兼ね備えた全天候、全用途対応のオールラウンド ウェアを開発することを狙いとし、防風機能編地『ウィン ドバリア®』の開発に着手した。

\section{3 . 開発の目標設定}

一般的に防風機能性は通気量 $\left(\mathrm{cc} / \mathrm{cm}^{2} \cdot \mathrm{sec}\right)$ で評価し、 数值が小さいほど優れた防風機能を有すると判断される。 現状のニッ卜商品は生地により差はあるが、通常 100〜200 $\mathrm{cc} / \mathrm{cm}^{2} \cdot \mathrm{sec}$ の通気量があるため、夏場は快適であるが、 特に冬場の強風時には風を通すため寒く、通常は織物のア ウターウェアを着用するのが一般的であった。

一方、高密度織物は $3 \mathrm{cc} / \mathrm{cm}^{2} \cdot \mathrm{sec}$ 以下の通気量しかな いので、逆に夏場にはムレ感があり快適とはいえなかった。

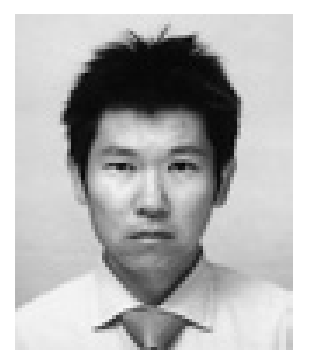

NOBUAKI OGATA

帝人ファイバー(蛛) 加工技術グループ

スポーツインナー開発チーム スポーツ

担当

T541-8587 大阪市中央区南本町 1丁目 6 番 7 号

Tel : 06-6268-2445 Fax : 06-6268-2803

E-mail : no.ogata@teijin.co.jp

〈専門〉スポーツウェアの開発

〈趣味〉スノーボード、テニス

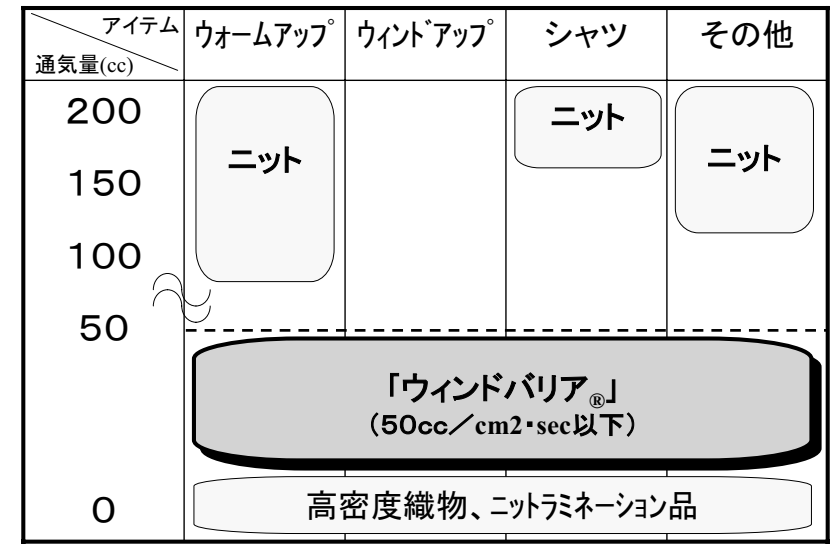

图 1 「ウィンドバリア $\left.{ }_{\circledast}\right\lrcorner$ の通気量目標レベル

弚こで今回は、一年を通して快適に着用できるウェアと して、通気量レベルの目標を $5 \sim 50 \mathrm{cc} / \mathrm{cm}^{2} \cdot \mathrm{sec}$ に設定し、 開発を行った(図 1)。

\section{4 . 既存技術}

従来から、(1)フィルムラミネーション(2)編地の極端な 高密度化といった手法により、ニット商品に防風性を付与 する技術が検討されてきた。

しかし、これらの手法では、製品としてニット本来のス トレッチ性やソフト風合い、嵩高性などが損なわれたり、 満足な防風性が得られないなどの問題点があった(表 1)。

表 1 既存防風ニット技術の問題点

\begin{tabular}{|c|c|c|}
\hline 既存技術 & 問題点 & \\
\hline 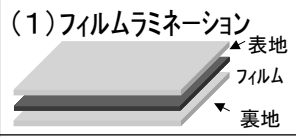 & $\begin{array}{l}\text { •風合いが硬い } \\
\text { • 発汗時の蒸れ感有り } \\
\text { •コストが高い }\end{array}$ & \multirow{2}{*}{$\begin{array}{c}\text { 二朴の特徵が } \\
\text { 損なわれる }\end{array}$} \\
\hline $\begin{array}{l}\text { (2) 編地の高密度化 } \\
\text { (従来商品を密度アップ) }\end{array}$ & $\begin{array}{l}\text { •ストレッチ性に乏しい } \\
\text { •嵩高性に乏しい } \\
\text { •防風性能が低い }\end{array}$ & \\
\hline
\end{tabular}

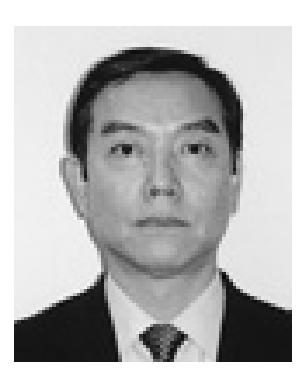

MIZUKI MITSUO

(株)帝健 開発・生産担当

于541-8587 大阪市中央区南本町 1丁目 6 番 7 号 帝人ビル

Tel : 06-6268-2569 Fax : 06-6268-2129

E-mail : m.mizuki@teijin.co.jp

$\langle$ 専門〉新規ニット商品の開発

〈趣味〉球技 


\section{5 . 防風機能付与技術}

優れた防風性を得る為には、風が通らないようにルーズ なニット構造の空隙を塞ぐことが必要である。

弚の空隙は

(1) ループ自体の空隙

(2) 隣り合うループ間の空隙

の大きく 2 種類に分類できる。

この2 種類の空隙を共に効果的に塞がなければ優れた防風 性は得られない。

兴の為に、今回は以下に示すような異なる 3 種類の手法 を複合させることにより優れた防風性を付与する事が可能 になった。

\section{1 編地の高密度化}

具体的な手法として

(a) 高収縮系交編

(b) 編機のハイゲージ化

(c) ループ最密充填組織の採用

が挙げられる。

これらの手法で、高密度な特殊編地構造が実現され、ルー プ自体の空隙はかなり塞ぐことが可能となる。しかしなが ら、これらの手法だけではループ間空隙はなかなか塞ぐこ とができない為、結果として満足な防風性を得ることは困 難であった(図 2)。

また、極端に高密度化するとニットの特徵が損なわれる 原因にもなる為、ここではループ自体の空隙を塞ぐことが できる最低限の条件で編成することが必要になる。

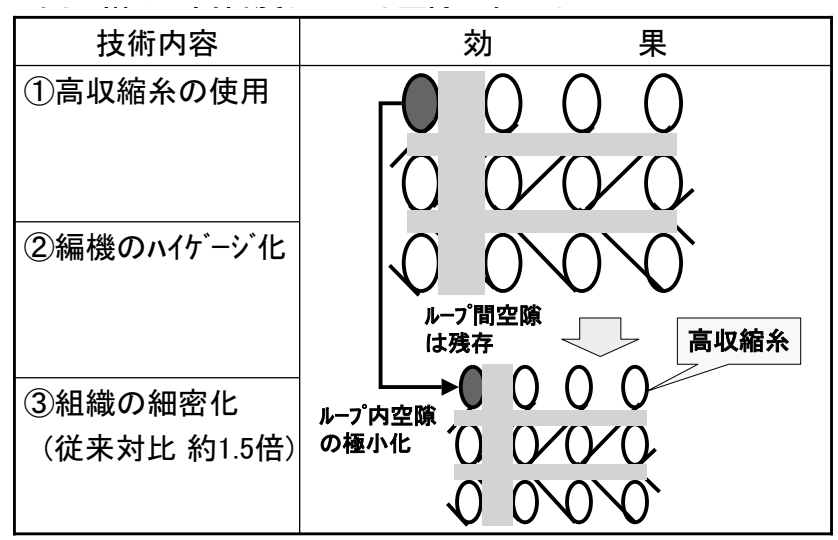

図 2 編地の高密度化による空隙の極小化

\section{2 通気抵抗を増大させる素材の開発}

上記の手法だけでは、塞ぐ事が出来ないループ間空隙を 塞ぐために、この空隙を抜ける風の通気抵抗が最大限とな る素材を検討した。

理論的には、フクラミのある細い繊維の集合体で構成す れば効果的と考えられるが、種々の素材を検討した結果、 単系太さが細く、捲縮率の高い加工系素材のほうが好まし いことが確認できた(図 3)。ただし単系太さが細くなるに 比例して捲縮率は低くなるので、両方の特性を満たす為に は、単系太さは $0.3 \sim 1.0$ デニールが最適であることが検証

\begin{tabular}{|c|c|c|}
\hline 技術内容 & 効 & 果 \\
\hline (1)単糸の細de化 & 39 & \begin{tabular}{|l} 
単糸de \\
$0.3 \sim 1.0 \mathrm{dpf}$
\end{tabular} \\
\hline (2)原糸の高捲縮化 & $\overline{\underline{\underline{\underline{\underline{\underline{\underline{\alpha}}}}}}}$ & 捲縮率 $\geqq 10 \%$ \\
\hline
\end{tabular}

図 3 編地空隙の通気抵抗を増大させる素材開発

できた。このような素材を編込むことによりループ間の空 隙を塞ぐことが可能になった。

\section{3 特殊染色加工技術}

上記で述べたような、生機編成段階での工夫により空隙 をかなり塞ぐことができるが、これらの効果をさらに高め る為に、染色加工での工夫が必要である。

元来ニットは、染色加工工程中に生地が伸びきってしま い高密度仕上げか灘しいという特性をもっている。これを 防ぐ為、できるだけタテ方向の張力がかからず、強いリラッ クス効果が得られる工程を検討した結果、最大限の高密度 化及び捲縮発現が可能になった(表 2)。

表 2 特殊染色加工技術

\begin{tabular}{|c|c|}
\hline 技術内容 & 効 \\
\hline $\begin{array}{l}\text { (1)加工時の } \\
\text { 揉み効果強化 }\end{array}$ & $\begin{array}{l}\text { •高収縮糸の収縮UP } \\
\text { •高捲縮糸の捲縮を最大限発現 }\end{array}$ \\
\hline (2)低張力加工 & $\begin{array}{l}\text { •タテ方向の張力抑制 } \\
\text { •生地伸び防止 }\end{array}$ \\
\hline
\end{tabular}

$$
\text { 6.『ウィンドバリア®』の性能 }
$$

これまで述べてきた手法により開発した『ウィンドバリ

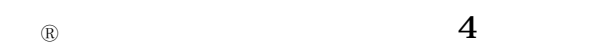
従来品に比べてループ自体が高密度化され、ループ間空隙 も極細高捲縮系で塞がれている事が確認できる。 光の結果、優れた防風性を付与することが出来た。

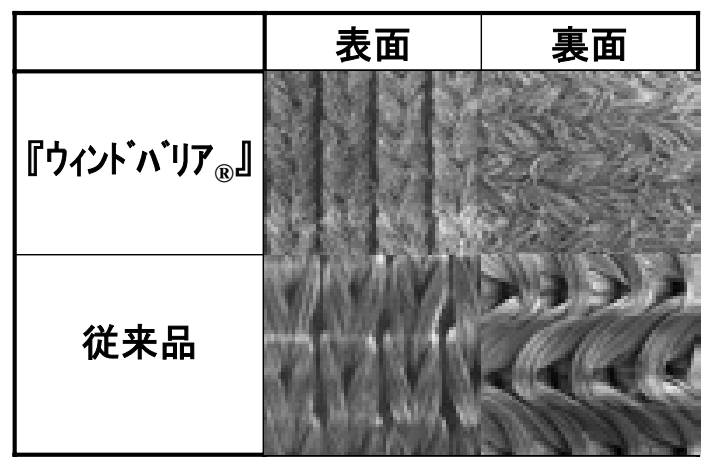

図 4 『ウィンドバリア®』の編地表面形態比較

『ウィンドバリア®』の基本特性を(表 3)に示す。

現在開発品の通気量は、7〜 40cc $/ \mathrm{cm}^{2} \cdot \sec$ の優れた防 風機能性を持っている。

一方で、ニットの特徵であるストレッチ性や嵩高性は損 なわれておらず、ニットと織物の特徵を併せ持つ全く新し い商品として市場に展開できる商品と考えている。 
表 3 「ウィンドバリア®」の機能レベル

\begin{tabular}{|c|c|c|c|c|}
\hline \multicolumn{2}{|l|}{ 項目 } & 従来二扑商品 & 『ウインドバリア 』 & 高密度織物商品 \\
\hline \multicolumn{2}{|c|}{$\begin{array}{c}\text { 通気量 } \\
\left(\mathrm{cc} / \mathrm{cm}^{2} \cdot \mathrm{sec}\right)\end{array}$} & $>100$ & $7 \sim 40$ & $<1$ \\
\hline \multicolumn{2}{|c|}{$\begin{array}{l}\text { 嵩高性 } \\
\left(\mathrm{cm}^{3} / \mathrm{g}\right)\end{array}$} & 4.0 & 4.4 & 1.5 \\
\hline \multirow{2}{*}{$\begin{array}{c}\text { 자レッチ性 } \\
(\%)\end{array}$} & 夕' & $25 \sim 35$ & $20 \sim 35$ & $<5$ \\
\hline & $\exists \exists$ & $40 \sim 50$ & $20 \sim 35$ & $<5$ \\
\hline
\end{tabular}

7 . 消費科学的な機能性の評価

\section{1 防風保温性評価}

今回開発した『ウィンドバリア®』の防風保温性能を当 社の大阪研究センターにおいて着用試験を実施して検証し た。

室温 $10^{\circ} \mathrm{C}$ に調節した人工気象室で、素肌に直接『ウィ ンドバリア®』を着用し、風速 $5 \mathrm{~m} / \mathrm{sec}$ の風を受けたとき の衣服内温度変化を測定した結果を図 5 に示す。

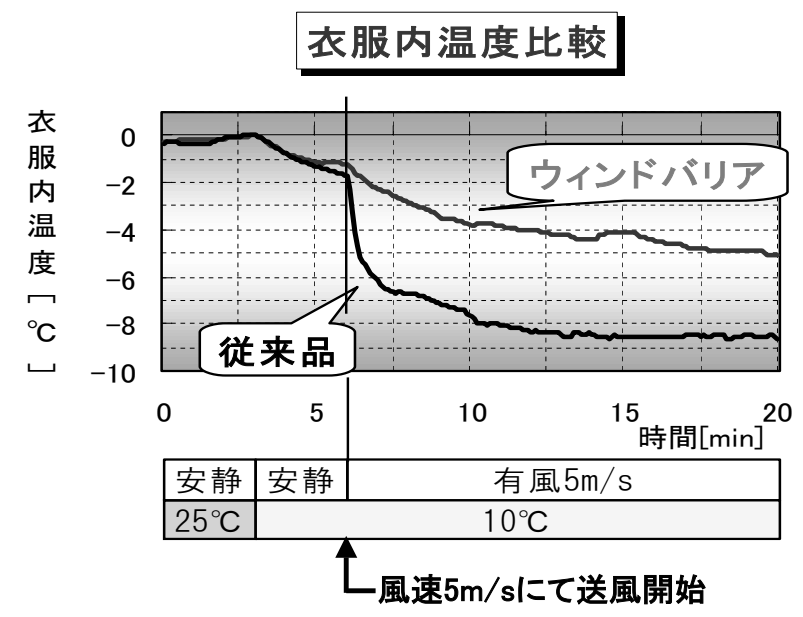

図 5 着用評価による衣服内温度変化比較

従来のニット商品では風を受け始めた直後に急激に温度 が低下するが、『ウィンドバリア®』では急激な温度低下 は見られないことが分かる。結果的に、15 分後には約 $4^{\circ} \mathrm{C}$ の優位性があった。

私も実際、被験者として着用したが、従来品は風が編地 を突き抜けチクチク肌を差すような感じであり、明らかに 『ウィンドバリア®』の優位性を体感できた。

\section{2 ノイズレス性評価}

織物に比べてニット商品は着用時のノイズレス性に優れ ることは実感として明らかであるが、今回『ウィンドバリ ア®』のノイズレス性能を数值化することを試みた。

生地を摩擦させた時に発生するノイズをマイクで受信し $\mathrm{dB}$ 表示した数值を表 4 に示す。

数值として $10 \mathrm{~dB}$ の差が、体感では約 2 倍に相当すると いう知見から、織物対比 2 倍以上のノイズレス性能を持つ ことが分かる。
表 4 『ウィンドバリア®』ノイズレス性評価

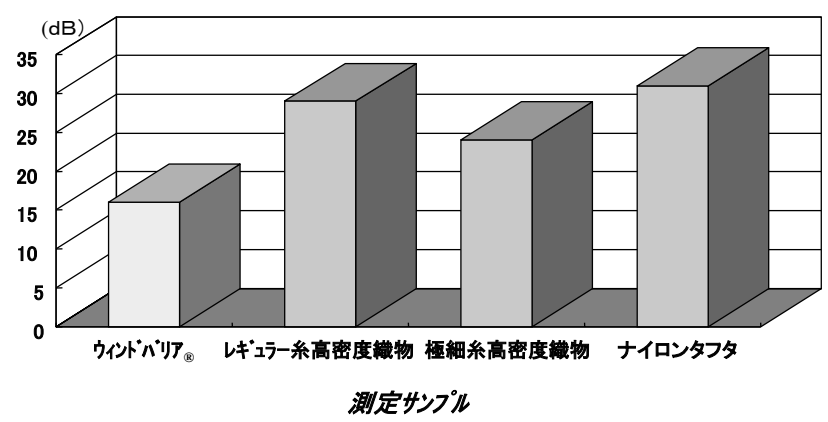

\section{3 撥水性評価}

『ウィンドバリア®』は高密度構造を持つ為、撥水加工 を施すことで、優れた撥水性を示す。

優れた撥水性能を独自の方法で数値化することを試みた。 生地の上に水滴を滴下し、生地の傾斜角度を変化させた 時の、水滴の転がり始める角度で評価する『ころがり角度 法』で測定した DATAを表 5 に示す。

表 5 『ウィンドバリア®』の撥水性評価

\begin{tabular}{|c|c|c|}
\hline & 生地方向 & 傾斜角度 $\left(\theta^{\circ}\right)$ \\
\hline \multirow{2}{*}{ ウインドバリア } & 多 & 8 \\
\hline & $\exists$ & 6 \\
\hline \multirow{2}{*}{$\begin{array}{c}\text { 超撥水 } \\
\text { 高密度織物 }\end{array}$} & 多 & 6 \\
\hline & ב & 5 \\
\hline \multirow{2}{*}{ ナイロンタフタ } & 行 & 14 \\
\hline & ヨコ & 18 \\
\hline
\end{tabular}

これによると、織物の中でも最も優れているといわれて いる超撥水織物と同等レベルの優れた撥水性を持っている ことが分かった。

\section{8. シリーズ化による商品拡充}

上記で説明したように、『ウィンドバリア®』は優れた 防風保温性を持った商品であるが、これ加えて、スポーツ ウェアの基本的な 4 種類の新たな機能を付与した『ウィン ドバリア®シシリーズを商品化して、あらゆるスポーツシー ンに対応できるウェア素材として幅広く市場展開を行って

表 6 『ウィンドバリア®』シリーズの商品内容

\begin{tabular}{|c|c|}
\hline ブランド名 & 付与手段 \\
\hline $\begin{array}{c}\text { ウイドバリア } \boldsymbol{乃}_{\circledast} \mathbf{W P} \\
\text { (防風撥水) }\end{array}$ & 耐久撥水·カレンダー \\
\hline $\begin{array}{r}\text { ウイントバリアア } \\
\text { (防風吸汗) }\end{array}$ & $\begin{array}{c}\text { 裏表の粗密構造 } \\
\text { 吸汗加工 }\end{array}$ \\
\hline $\begin{array}{r}\text { ウインドバリア } \\
\quad \text { (防風ストレッチ） }\end{array}$ & ストレッチ糸交編 \\
\hline $\begin{array}{r}\text { ウイントバリア }{ }_{\circledast} \mathbf{W M} \\
(\text { 防風保温） }\end{array}$ & 起毛加工 \\
\hline
\end{tabular}


いる(表 6)。

9.『ウィンドバリア ${ }_{\circledast 』 の}$ の商品特徵

(1) 優れた防風保温性

（2）ソフトな風合いと適度なストレッチ性 (ニット本来の特徵を損なわない)

(3) 優れたノイズレス機能 (高密度織物対比約 2 倍の性能)

（4）優れた撥水性能

(超撥水織物と同等レベル
（5）シリーズ化により、樣々な用途展開が可能 (従来ニット用途と新たな用途参入)

$$
\text { 10.おわりに }
$$

防風機能編地『ウィンドバリア®』は、従来のニット商 品の用途に加えて、従来ニットでは参入できなかった織物 用途への展開も可能となり、新しい商品市場を構築できた。 今後は、さらに新しい機能を付与し、シリーズを拡充す ることにより、新機能商品の開発に注力していきたい。

\section{第 43 回機能紙研究発表・講演会}

主 催 : 特定非営利活動法人 機能紙研究会

共 催 : (財)日本産業技術振興協会

協 賛 : (社)繊維学会ほか

$\diamond$ 研究発表・講演会

日 時: 平成 16年 10 月 28 日(杖 $9: 00 \sim 17: 30$

会 場 : (財)大阪科学技術センター・大ホール

干 550-0004 大阪市西区鞄本町 1-8-4 TEL : 06-6443-5324

○ポスター研究発表及び新製品展示会

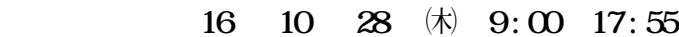

会 場: (財)大阪科学技術センター・8階ロビー

$\diamond$ 見学会

日 時: 平成 16 年 10 月 29 日(金) $8: 30 \sim 17: 30$ (予定)

見学先: 〈A コース〉(定員)100名・バス 2 台・姫路方面)

午前：王子製紙(株)神崎工場 午後 : オプトピア

最終 : JR 姫路駅

〈B コース〉(定員)40名・バス 1 台・京都方面)

午前：松下電器産業(株) 午後 : GS・YUASA コー ポレーション 最終 : JR 京都駅

（見学会コースのご希望は、先着順にて受付、定員になり 次第締め切らさせて頂きます。

尚、両コースとも、同業者等はご遠慮頂く場合がありま す。

参加費 : 研究発表 ·講演会 一般会員 10,000円

賛助会員 8,000 円

学生会員 6,000 円

交 流 会 (一律) 10,000円

プログラム

見学会 (一律) 10,000円

主題『新しい機能に挑む〜高機能紙への胎動〜』

$\langle$ 午前の部〉

開会挨拶 機能紙研究会会長 稲垣 寛 9:00 9:10

来賓祝辞

$9: 10 \sim 9: 20$

(1)セルロースのナノ構造制御による新機能材料の創製 $9: 20 \sim 9: 50$

徳島文理大学工学部ナノ物質工学科教授 岡島 邦彦

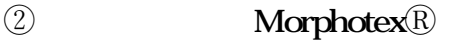
$9: 50 \sim 10: 20$

帝人ファイバー(株)モルフォ推進室長 能勢 健吉 (3)インテリジェント材料を利用した機能紙の開発

$10: 20 \sim 10: 50$

- 自己発色性マイクロカプセルを一例として -
愛媛県紙産業研究センター特別研究員 市浦 英明 (4)バナナ・パイナップル繊維のパルプ化及び製紙適性

$10: 50 \sim 11: 20$ 岐阜県製品技術研究所美濃分室専門研究員 小川 俊彦 [特別講演]

(5)21世紀の繊維材料の展望

$11: 20 \sim 12: 20$ $\langle$ 午後の部〉

信州大学繊維学部教授(繊維学会会長)白井 汪芳

〈通常総会〉

[特別講演]

$13: 20 \sim 13: 40$

(6)アメリカにおける紙パルプ研究事情

- IPST での8年

13: 40 14: 40

Institute of Paper Science and Technology, Georgia

Institute of Technology Principal Research Scientist

南光 浩毅

(7)水素をつくる機能紙 - 燃料電池用ペーパー触媒の開発 $14: 40 \sim 15: 10$

九州大学大学院農学研究院森林資源科学部門助教授

北岡 卓也

8)電子ペーパーの技術動向 15:10〜15:40

王子製紙(制新技術研究所上級研究員 前田 秀一 〈休咊〉 15:40〜15:55

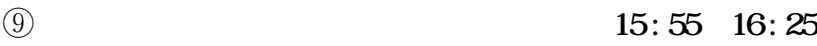
京都女子大学家政学部教授 矢井田 修

(10)写真印画紙用支持体を再利用したホワイト積層ボードの 展開

$16: 25 \sim 16: 55$

三菱製紙(株)機能材料事業部担当課長 伊藤 和彦

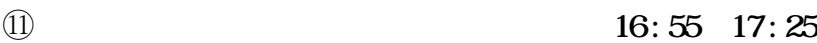

静岡県富士工業技術センター研究主幹 日吉 公男

閉会挨拶

$17: 25 \sim 17: 30$

産学官技術交流会

$17: 30 \sim 17: 55$

〜ポスターセッション会場にて質疑応答形式での技術交 流〜

問合せ先 : † 799-0101 四国中央市川之江町 4084 番 1 特定非営利活動法人 機能紙研究会事務局 (担当-森川 : 紀伊 : 石川) TEL : 0896-58-2055 FAX : 0896-58-6240 E-mail : kinoushi@us.ehime-iinet.or.jp 